\title{
THE ROLE OF THE SUPREME COURT IN THE DEVELOPMENT OF A CANADIAN LAW OF RESTITUTION
}

\author{
NICHOLAS RAFFERTY
}

In this essay, the author examines the emerging law of restitution and the peculiar and powerful contribution of the Supreme Court of Canada to its development and maturation. It is argued that the Supreme Court has assumed a leading role in fashioning the modern law of restitution in the Commonwealth. The first part of the paper traces the adoption and elaboration by the Canadian courts of a general principle of unjust enrichment with respect to both personal and proprietary claims. This involves an examination of specific cases in which the Supreme Court has embraced both the principle of unjust enrichment and the independent nature of the law of restitution. The essay then analyzes the contribution of the Supreme Court in applying that general principle across the full spectrum of restitutionary liability. Particular attention is focused upon the recognition of a defence of change of position, the recovery of benefits conferred under mistake, contribution among concurrent wrongdoers and the development of the remedial constructive trust. The author concludes that, despite the significant progress made by the Supreme Court, there are a number of areas in which further work is required to develop fully the principle of unjust enrichment.
L'auteur examine l'émergence du droit de restitution et la contribution particulièrement importante de la Cour suprême du Canada à son évolution et à sa maturation. L'auteur soutient que la Cour suprême a joús un rôle de pointe dans le façonnement du droit de restitution moderne au sein du Commonwealth. En première partie, il retrace l'adoption et l'élaboration par les tribunaux canadiens d'un principe général d'enrichissement sans cause concernant les créances personnelles et les actions propriétales. Ceci implique l'examen de cas spécifiques où la Cour suprême invoque à la fois le principe d'enrichissement sans cause et la nature indépendante du droit de restitution. L'auteur analyse ensuite la contribution de la Cour suprême en ce qu'elle applique ce principe général à toute la gamme des obligations de restitution. Une attention particulière est accordée à la reconnaissance d'une défense de changement de position, au recouvrement d'avantages conférés par erreur, à la contribution parmi les coresponsables d'un préjudice et à l'élaboration de la fiducie judiciaire réparatrice. L'auteur conclut que, malgré les progrès importants réalisés par la Cour suprême, un certain nombre de secteurs exigent encore l'élaboration plus complète du principe d'enrichissement sans cause.

\section{TABLE OF CONTENTS}

I. INTRODUCTION .................. 558

II. THE PRINCIPLE OF UNJUST ENRICHMENT . . . . . . . . . 559

III. APPLICATION OF THE PRINCIPLE OF

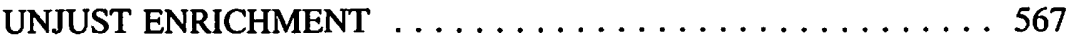

A. DEFENCE OF CHANGE OF POSITION .......... 567

B. RECOVERY OF BENEFITS CONFERRED

UNDER MISTAKE . . . . . . . . . . . . . . . 569

C. CONTRIBUTION AMONG

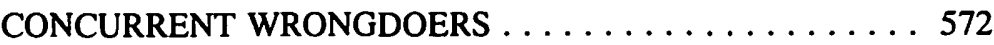

D. THE REMEDIAL CONSTRUCTIVE TRUST $\ldots \ldots \ldots \ldots 574$

IV. CONCLUSION ........................ 579 


\section{INTRODUCTION}

The book of which this article forms part is focused upon important developments in the law that have transpired over the past quarter of a century. On the private law side, arguably the most significant legal advance has been the acceptance, elaboration and maturation of that area of the law of obligations known as restitution. Indeed, it was only a little more than twenty-five years ago that the influential textbook by Robert (now Lord) Goff and Gareth Jones was first published. ${ }^{1}$ This book, now in its third edition, ${ }^{2}$ provided the initial structure and organization in Anglo-Canadian law for the subject of restitution. It is a remarkable work drawing together seemingly disparate threads of legal doctrine to form a coherent whole. In its wake, three books in the area have been published in Canada, ${ }^{3}$ the most recent of these in 1990. A further textbook has been published in England ${ }^{4}$ in which the author candidly admits that his work "would never have been so much as attempted" ${ }^{\text {I }}$ without the benefit of Goff \& Jones. A book of essays on restitution has been published in Australia. ${ }^{6}$ The subject is taking shape.

This essay concentrates upon the peculiar and substantial contribution of the Supreme Court of Canada to the law of restitution. This is an area in which the Supreme Court has been prepared to assume a leading role in the exposition of the law and has not been constrained by the conservative approach of, in particular, the English judiciary. Moreover, the efforts of the Supreme Court have filtered down to the lower courts with the result that restitution in Canada is a dynamic subject. Although the Canadian decisions, particularly in the context of the remedial constructive trust, have not escaped criticism, ${ }^{7}$ they have done much to fashion a modern law of restitution. ${ }^{8}$

The majority of the important Supreme Court decisions considered in this paper were rendered in the last twenty-five years. The primary exception is Deglman v. Guaranty Trust Co. of Canada. ${ }^{9}$ The judgment in that case was released in 1954. It constitutes the starting-point for the development of a Canadian law of restitution. It recognized restitution as a discrete subject, separate and apart from the law of contract, founded on

R. Goff \& G. Jones, The Law of Restitution (London: Sweet and Maxwell, 1966).

Lord Goff \& G. Jones, The Law of Restitution, 3d ed. (London: Sweet and Maxwell, 1986).

G.H.L. Fridman \& J.G. McLeod, Restitution (Toronto: Carswell, 1982); G.B. Klippert, Unjust Enrichment (Toronto: Butterworths, 1983); P.D. Maddaugh \& J.D. McCamus, The Law of Restitution (Aurora: Canada Law Book, 1990).

$4 \quad$ P. Birks, An Introduction to the Law of Restitution (Oxford: Clarendon Press, 1985).

$5 \quad$ Ibid. at 3.

$6 \quad$ P.D. Finn, ed., Essays on Restitution (Sydney: The Law Book Co., 1990).

7 For example, see D. Hayton, "Constructive Trusts: Is the Remedying of Unjust Enrichment a Satisfactory Approach?" in T.G. Youdan, ed., Equity Fiduciaries and Trusts (Toronto: Carswell, 1989) at 205; Hon. Mr. Justice W.M.C. Gummow, "Unjust Enrichment, Restitution and Proprietary Remedies" in Finn, ed., supra note 6 at 47; G.H.L. Fridman, "The Reach of Restitution" (1991) 11 Leg. Stud. 304.

* See generally J.D. McCamus, "Restitution and the Supreme Court: The Continuing Progress of the Unjust Enrichment Principle" (1991) 2 Sup. Ct. L.R. (2d) 505 [hereinafter "Restitution and the Supreme Court"]; J.D. McCamus, "Chief Justice Dickson and the Law of Restitution" (1991) 20 Man. L.J. 338 [hereinafter "Dickson C.J. and Restitution"].

y [1954] S.C.R. 725 [hereinafter Deglman]. 
the principle of unjust enrichment. The first part of this paper traces the adoption and elaboration by the Canadian courts of a general principle of unjust enrichment with respect to both personal and proprietary claims. The article then analyzes the substantial contribution of the Supreme Court in applying that general principle across the whole spectrum of restitutionary liability.

\section{THE PRINCIPLE OF UNJUST ENRICHMENT}

In 1937, the American Law Institute published its influential Restatement of the Law of Restitution, ${ }^{10}$ drafted by Professors Warren A. Seavey and Austin W. Scott of Harvard University. This work forms the foundation of the modern law of restitution. The first section of the Restatement gives expression to the general principle of unjust enrichment as the common thread underlying the whole subject. It provides at $§ 1$ : "A person who has been unjustly enriched at the expense of another is required to make restitution to the other."

Initially this principle, and the Restatement, received a warm welcome in England, especially by Lord Wright. Writing in 1937, he stated that restitution was "a distinct branch of law, capable of, and worthy of, careful study." ${ }^{\text {"1 }}$ He emphasized the same point in his judgment in Fibrosa Spolka Akcyjna v. Fairbairn Lawson Combe Barbour $L t .^{12}$ in the following oft-quoted words:

It is clear that any civilized system of law is bound to provide remedies for cases of what has been called unjust enrichment or unjust benefit, that is to prevent a man from retaining the money of or some benefit derived from another which it is against conscience that he should keep. Such remedies in English law are generically different from remedies in contract or in tort, and are now recognized to fall within a third category of the common law which has been called quasi-contract or restitution. ${ }^{13}$

Despite the early promise offered by Lord Wright's views, and the pioneering work of Goff \& Jones, there is in England as yet no general recognition of a principle of unjust enrichment. In 1977, Lord Diplock, for example, felt free to say that "there is no general doctrine of unjust enrichment recognized in English law." ${ }^{14}$ Moreover, recent judgments of the House of Lords in the field of tort law suggest that it may be a long time before the English courts are prepared to support a general right to restitution based upon the principle of unjust enrichment. The modern English view of tort liability is opposed to the application of some general test to determine whether a defendant owes a duty of care in negligence in favour of working by analogy from existing categories of negligence on a case by case basis. ${ }^{15} \mathrm{~A}$ similar approach in the field of restitution would tend to stultify the development of that branch of the law.

$1 \quad$ Rt. Hon. Lord Wright, "Sinclair v. Brougham" (1936-1938) 6 Camb. L.J. 305 at 322.

12 [1943] A.C. 32 (H.L.) [hereinafter Fibrosa Spolka].

$13 \quad$ Ibid. at 61.

$14 \quad$ Orakpo v. Manson Investments Ltd., [1977] 3 All E.R. 1 at 7 (H.L.).

is See in particular, Caparo Industries p.l.c. v. Dickman, [1990] 1 All E.R. 568 (H.L.); Murphy v. Brentwood District Council, [1990] 2 All E.R. 908 (H.L.). 
On the other hand, the influence of Robert Goff, now that he sits in the House of Lords, must not be understated. As a trial judge, he wrote:

[A] claim [for an award of restitution], being founded on the principle of unjust enrichment, presupposes three things: (1) receipt by the defendant of a benefit, (2) at the plaintiff's expense, (3) in such circumstances that it would be unjust to allow the defendant to retain the benefit. ${ }^{16}$

Indeed, he has recently given the leading judgment in two very important restitutionary decisions to be considered later in this paper, Lipkin Gorman v. Karpnale Ltd. ${ }^{17}$ and Woolwich Equitable Building Society v. Inland Revenue Commissioners. ${ }^{18}$ It is worth noting, however, that, in the Woolwich case, Lord Goff was in a slim majority and another member of that majority, Lord Browne-Wilkinson, although agreeing with the reasons of Lord Goff, wrote that "as yet there is in English law no general rule giving the plaintiff a right of recovery from a defendant who has been unjustly enriched at the plaintiff's expense."19 Quoting the famous words of Lord Wright in Fibrosa Spolka ${ }^{20}$ however, Lord Browne-Wilkinson did recognize that "the concept of unjust enrichment lies at the heart of all the individual instances in which the law does give a right of recovery."21

In Canada, the principle of unjust enrichment and the independent nature of the law of restitution was embraced, as has been mentioned, by the Supreme Court almost 40 years ago in the Deglman 22 case. The plaintiff had performed various services of a personal nature for his aunt on the faith of her oral promise to make adequate provision for him in her will and, in particular, to leave him a certain parcel of land. The aunt died intestate. The contract was unenforceable as contravening the Statute of Frauds. ${ }^{23}$ The Court held that there were insufficient acts of part performance to take the agreement beyond the reach of the statute. It determined, however, that the nephew could recover from the estate on the basis of a quantum meruit for the reasonable value of the services rendered. Such recovery was independent of any contract between the parties and was based upon the principle of unjust enrichment. The only relevance of the contract was the inference to be drawn from it that the services had not been supplied gratuitously. Nor did such recovery undermine the statutory policy. Thus, Rand J. said:

On the findings of both courts below the services were not given gratuitously but on the footing of a contractual relation: they were to be paid for. The statute in such a case does not touch the principle of restitution against what would otherwise be an unjust enrichment of the defendant at the expense of the plaintiff. ${ }^{24}$

B.P. Exploration Co. (Libya) Ltd. v. Hunt (No.2), [1982] 1 All E.R. 925 at 969 (Q.B.D.). Goff J.'s decision in the case was affirmed by the Court of Appeal, at 970, and by the House of Lords, at 986 . [1991] 2 A.C. 548 (H.L.).

[1992] 1 W.L.R. 366 (H.L.) [hereinafter Woolwich].

Ibid. at 414.

Supra note 12 at 61.

Supra note 18 at 414.

Supra note 9.

1677, 29 Car. II, c. 3, s. 4.

Supra note 9 at 728. 
In a similar vein, Cartwright J., relying upon Lord Wright's judgment in Fibrosa Spolka ${ }^{25}$ stressed the fact that the liability to make restitution was not dependent upon some implied contract between the parties but was founded upon an obligation imposed by law.

The importance of the Supreme Court's acceptance of a law of restitution based upon the principle of unjust enrichment is well illustrated by its later decision in County of Carleton v. City of Ottawa. ${ }^{26}$ For a number of years the plaintiff county, pursuant to a contract between the two municipalities, had cared for an indigent woman by paying for her placement in a home maintained by the County of Lanark. The plaintiff mistakenly believed that it was under a statutory obligation ${ }^{27}$ to look after the indigent as one of its residents. In fact, for the previous ten years, the maintenance of the indigent had been the responsibility of the defendant city because the city had annexed that part of the plaintiff county in which the indigent resided. When the plaintiff discovered its mistake, it sought to recover from the defendant the expenses it had incurred in caring for the indigent. The Supreme Court allowed the plaintiff's claim. Relying upon Deglman ${ }^{28}$ and Lord Wright's judgment in Fibrosa Spolka ${ }^{29}$ Hall J. said simply that it was "against conscience ${ }^{\text {"30 }}$ that the defendant should escape responsibility for the maintenance of the indigent in question as a result of mere inadvertence on the plaintiff's part.

The Court's conclusion is interesting because, on the basis of the existing authorities, there was no obvious ground on which liability should have attached to the defendant. The facts of the case most closely raised the principle that, where one party has been compelled by law to discharge the primary liability of another, the first party is entitled to reimbursement from the second party. ${ }^{31}$ Indeed, this was the basis of the claim advanced by the plaintiff.

The problem with applying that theory, however, was the fact that the plaintiff was not under any legal obligation to look after the indigent. It just believed that it had such an obligation. It was true that, as a result of its mistake, the plaintiff had bound itself contractually with the County of Lanark to pay for the indigent's maintenance and, in that sense, could be said to have been legally compelled to discharge the defendant's primary obligation. ${ }^{32}$ Such reasoning, however, would lead to the conclusion that the plaintiff would have failed had it cared for the indigent directly rather than by means of a contract with a third party. ${ }^{33}$ Moreover, there is still some doubt as to the extent to which a

Supra note 12 .

[1965] S.C.R. 663.

See The Homes for the Aged Act, R.S.O. 1950, c. 168 (now Homes for the Aged and Rest Homes Act, R.S.O. 1990, c. H.13).

Supra note 9.

Supra note 12.

Supra note 26 at 669.

See Moule v. Garrett, (1872) L.R. 7 Ex. 101; Brook's Wharf \& Bull Wharf Lid. v. Goodman Bros., [1937] 1 K.B. 534 (C.A.).

This seems to have been the reasoning of the trial judge in deciding the case in favour of the plaintiff, see (1963) 39 D.L.R. (2d) 11 (Ont. H.C.).

See Maddaugh \& McCamus, supra note 3 at 17. 
plaintiff can claim reimbursement for the compulsory discharge of another's liability where the compulsion arises out of a contract voluntarily entered into by the plaintiff. ${ }^{34}$ The importance of the Supreme Court's decision lies in the fact that that body made no attempt to fit the case precisely into some pre-existing basis for liability.

The reasoning of the Supreme Court in Deglman and County of Carleton has had a profound influence on the lower courts. Thus, in James More \& Sons Ltd. v. University of Ottawa, ${ }^{35}$ Morden J. pointed out that, in order to grant relief in restitution, it was not necessary to fit the facts of the case into some pre-existing category established by precedent. He continued: "[j]ust as the categories of negligence are never closed, neither can those of restitution. The principles take precedence over the illustrations or examples of their application. ${ }^{136}$

In White v. Central Trust Co. ${ }^{37}$ La Forest J.A. also accepted the existence of a general principle of unjust enrichment and determined that "the law [would] afford a remedy for unjust enrichment in the absence of valid judicial policy militating against it. ${ }^{38} \mathrm{He}$ did, however, counsel against an indiscriminate use of that principle. He said that, in applying the principle to new situations, it often made the most sense to work by analogy from existing categories provided that the courts bore in mind that the general principle transcended the well-recognized categories of unjust enrichment. This is wise advice. The courts must take care that restitution does not become a cure-all for every legal ill. As with a contracts or a torts case, for example, the courts must continue to analyze and synthesize the relevant authorities. They must not operate on vague notions of fairness and justice, but must "look downwards to the cases. ${ }^{39}$ The general principle of unjust enrichment, however, is there to guide them in the orderly growth of the law so that it can adapt to novel situations.

Recently, in Peel (Regional Municipality) v. Canada; Peel (Regional Municipality) v. Ontario, ${ }^{40}$ the Supreme Court emphasized the fact that the courts, in granting restitutionary relief, were not restricted to the traditional categories in which recovery had been granted. On the other hand, when extending the boundaries of recovery based upon the general principle of unjust enrichment, the courts had to tread warily to ensure that relief was warranted under that principle and not to merely invoke some vague concept of justice. Thus, McLachlin J. wrote:

This case presents the court with the difficult task of mediating between, if not resolving, the conflicting views of the proper scope of the doctrine of unjust enrichment. It is my conclusion that we must choose a middle path; one which acknowledges the importance of proceeding on general principles but seeks to

For example, see Lambert Implements Ltd. v. Pardell (1964), 50 W.W.R. 310 (Alta. D.C.); Owen v. Tate, [1975] 2 All E.R. 129 (C.A.). (1974), 49 D.L.R. (3d) 666 (Ont. H.C.).

Ibid. at 676.

(1984), 7 D.L.R. (4th) 236 (N.B.C.A.).

lbid. at 245.

Birks, supra note 4 at 23.

(1992), 98 D.L.R. (4th) 140 (S.C.C.) [hereinafter Peel]. 
reconcile the principles with the established categories of recovery; one which charts a predictable course without falling into the trap of excessive formalism; one which recognizes the importance of the right to choose where to spend one's money while taking account of legitimate expectations and what, in light of those expectations, is fair. ${ }^{41}$

McLachlin J. therefore saw the need for the courts to be flexible in their approach and not to be wedded to the traditional categories, while at the same time grounding their decisions in principle. She said: "recovery cannot be predicated on the bare assertion that fairness so requires. A general congruence with accepted principle must be demonstrated as well."142 She found the necessary flexibility in the unjust enrichment principle as formulated by the Supreme Court in the matrimonial property cases considered below.

Peel itself raised an interesting problem. By court orders made pursuant to s. 20(2) of the Juvenile Delinquents $A c t,{ }^{43}$ the plaintiff municipality was compelled to contribute to the support of juvenile delinquents. The municipality later successfully challenged the constitutionality of this provision as being beyond the powers of Parliament. In these actions, the municipality was seeking restitution of the payments made from the provincial and federal governments.

The Court rejected the plaintiff's claims on the simple ground that no benefit had been bestowed on the defendants. McLachlin J. said that the whole concept of "restitution" entailed the restoration of some benefit conferred. She determined that some enrichment of the defendant was an essential element in the granting of relief, whether the Court worked within the traditional categories or applied the general principle of unjust enrichment.

McLachlin J. recognized that the requisite benefit could be negative rather than positive in the sense that the recipient was spared an expense. The classic example of such a benefit would be the discharge of a legal liability owed by the defendant. In this case, however, the payments made by the municipality had not discharged the legal liability of either defendant. Neither the federal nor the provincial government was held to be under a legal obligation to provide for the care of the children.

McLachlin J.'s determination of no benefit meant that the case could not fall within the traditional category, outlined above, of the compulsory discharge of another's liability. McLachlin J. then concluded that the conferral of a benefit was also required where a court was inclined to take a broader approach based upon the principle of unjust enrichment. She pointed out, for example, that, while relief had been granted outside of the traditional categories, in County of Carleton v. City of Ottawa ${ }^{44}$ the defendant had certainly received a benefit there in the form of a discharge of its legal liability. For the purpose of argument, McLachlin J. was willing to assume that a benefit could take the

43 R.S.C. 1970, c. J-3. This statute has since been replaced by the Young Offenders Act, R.S.C. 1985, c. Y-1. 
form of the saving of an expense that the defendant would inevitably have incurred, although not legally required to do $\mathrm{so}^{45}$ She held, however, that the plaintiff had failed to establish that either the provincial or the federal government would inevitably have paid for the children's care in the absence of the plaintiff's payments. There was no concept of restitution in a vacuum, only of restitution of specific benefits conferred.

All of the cases discussed to this stage have concerned the personal liability of a defendant to make restitution. The next development in the law, again promoted by the Supreme Court, was the recognition of the constructive trust as a general restitutionary proprietary remedy to prevent unjust enrichment. This development grew out of a series of cases dealing with the division of property upon the breakdown of a marriage or similar relationship. In Murdoch v. Murdoch, ${ }^{46}$ the question was whether a wife could claim a beneficial interest in a ranch registered in her husband's name as a result of the services she had rendered during the marriage in support of the parties' various ranching endeavours. The majority of the Court, in a judgment given by Martland J., rejected the wife's claim on the ground that no common intention could be inferred that the wife should have a beneficial interest in the property in question. Thus, no resulting trust in favour of the wife could come into existence. ${ }^{47}$ In his lone dissent, Laskin J. eschewed the traditional analysis and determined that the Court could impose a constructive trust on the husband to prevent his unjust enrichment in light of his wife's substantial contribution of physical labour to the acquisition of successive properties leading to the ranch in question. Such a trust was not dependent upon any intention that a spouse should receive a beneficial interest in the property. Rather, it was a remedial device designed to prevent one party's unjust enrichment at the expense of another.

Five years later, in Rathwell v. Rathwell, ${ }^{48}$ Laskin C.J. was able to convince two of his colleagues of the rightness of his cause. In that case, a bare majority of the Court found in favour of the wife on the basis of a resulting trust. As part of that majority, however, Dickson J., with Laskin C.J. and Spence J. concurring, expressed his preference for the imposition of a constructive trust. He said that such a trust was imposed by the courts irrespective of the intention of the parties. He approved of the American view that the constructive trust was a proprietary remedy designed to combat unjust enrichment. He believed that the way had been cleared in Canada for the recognition of such a view by the general acceptance of a law of restitution in the Deglman ${ }^{49}$ case. He then stated his version of the principle of unjust enrichment in the following terms:

As a matter of principle, the Court will not allow any man unjustly to appropriate to himself the value earned by the labours of another. That principle is not defeated by the existence of a matrimonial relationship between the parties; but, for the principle to succeed, the facts must display an enrichment,

The so-called "incontrovertible benefit". See Goff \& Jones, supra note 2 at 19-22, 144-49; Maddaugh \& McCamus, supra note 3 at 42-44; Birks, supra note 4 at 116-24. [1974] 1 W.W.R. 361 (S.C.C.) [hereinafter Murdoch]. Martland J. relied upon the leading English decisions of Pettit v. Pettit, [1970] A.C. 777 (H.L.) and Gissing v. Gissing, [1971] A.C. 886 (H.L.). 
a corresponding deprivation, and the absence of any juristic reason - such as a contract or disposition of law - for the enrichment. ${ }^{50}$

Dickson J. concluded that the wife was entitled to a beneficial interest in the husband's farm lands, irrespective of any direct financial contributions made by her, because of the work she had carried out in running the farm. He said:

[I]t would be unjust in all of the circumstances, to allow Mr. Rathwell to retain the benefits of his wife's labours. His acquisition of legal title was made possible only through "joint effort" and "team work"... he cannot now deny his wife's beneficial entitlement. ${ }^{51}$

Finally, just two years later in Pettkus v. Becker, ${ }^{52}$ a majority of the Supreme Court, again in a judgment rendered by Dickson J., recognized the remedial constructive trust based on the principle of unjust enrichment to grant a "common law wife" a beneficial interest in the "husband's" farming business. This time Dickson J. stated unequivocally that the "principle of unjust enrichment lies at the heart of the constructive trust." ${ }^{.53}$

Of course, the constructive trust cases have been important not just for their recognition of the availability of proprietary restitutionary relief but also for their formulation and application of the principle of unjust enrichment. The threefold test for determining the existence of an unjust enrichment - an enrichment, a corresponding deprivation and the absence of any juristic reason for the enrichment - first propounded by Dickson J. in Rathwell ${ }^{54}$ and confirmed by him in Pettkus, ${ }^{55}$ has become the yardstick against which all restitutionary claims, and especially novel ones, must be measured. ${ }^{56}$ This is not to say that Dickson J.'s statement of the principle is flawless. Much of the modern law of restitution deals with situations where the defendant has made a gain through some breach of duty owed to the plaintiff. ${ }^{57}$ In these cases, the gain acquired by the wrongdoer will not necessarily correspond to any loss incurred by the claimant. ${ }^{58}$ This kind of case is not contemplated directly by Dickson J.'s words.

It is interesting to observe that the leading role assumed by the Supreme Court in the development of a principle of unjust enrichment has had an effect in other parts of the Commonwealth. Thus, in Pavey \& Matthews Pty. Ltd. v. Paul, ${ }^{59}$ a majority of the High

so Supra note 48 at 306.

s1 Ibid. at 310 .

s2 (1980), 117 D.L.R. (3d) 257 (S.C.C.) [hereinafter Pettkus].

$53 \quad$ lbid. at 273.

s4 Supra note 48 .

5s. Supra note 52 .

s6 For example, see the recent decision of the British Columbia Court of Appeal in Atlas Cabinets and Furniture Ltd. v. National Trust Co. Ltd. (1990), 68 D.L.R. (4th) 161. This case is also noteworthy for a strong dissent by Southin J.A. in which she questioned the application of a general doctrine of unjust enrichment outside of the family law context and exhibited a reluctance to extend the law of restitution beyond the established categories for relief. See generally Fridman, supra note 7 at 314-19. These situations are referred to by Birks, supra note 4, ch. X, as "Restitution for Wrongs". The classic example would be an action to strip a fiduciary of profits made through a breach of fiduciary duty. See generally Maddaugh \& McCamus, supra note 3, ch. 25.

(1987), 162 C.L.R. 221 (Aus. H.C.) [hereinafter Pavey \& Matthews]. 
Court of Australia determined that a licensed builder could recover on a quantum meruit for the value of work done and materials supplied under a contract rendered unenforceable by statute as not being in writing and signed by the parties. ${ }^{60}$ Such a claim was seen as one, not based on the contract, but to restitution founded on the principle of unjust enrichment. Deane J., for example, said:

[The concept of unjust enrichment] constitutes a unifying legal concept which explains why the law recognizes, in a variety of distinct categories of case, an obligation on the part of a defendant to make fair and just restitution for a benefit derived at the expense of a plaintiff and which assists in the determination, by the ordinary processes of legal reasoning, of the question whether the law should, in justice, recognize such an obligation in a new or developing category of case.... ${ }^{61}$

Not surprisingly, one of the leading authorities followed in Pavey \& Matthews was the decision of the Supreme Court in Deglman. ${ }^{62}$ Even the concept of the remedial constructive trust generated by the principle of unjust enrichment, as promoted by the Supreme Court, has garnered some support in Australia ${ }^{63}$ At the present time, however, at least in the context of family property disputes, the Australian courts seem to be moving in the direction of recognizing a constructive trust based on the similar notion of the defendant's unconscionable conduct. ${ }^{64}$ The important point is that the Canadian developments are having an influence in Australia. ${ }^{65}$

Having now embraced the principle of unjust enrichment, there are signs from some recent judicial pronouncements that the Australian courts might be willing to carry that principle even further than the Canadian courts, and perhaps too far. In Trident General Insurance Co. Ltd. v. McNiece Bros. Pty. Ltd. ${ }^{66}$ for example, Gaudron J. contemplated the use of that principle to justify the enforcement of a contractual promise by a third party beneficiary ${ }^{67}$ She wrote:

Builders Licensing Act, 1971 N.S.W. s. 45.

Supra note 59 at 256-57. It is interesting to note that, in his judgment in Pavey \& Matthews, Deane J. would appear to have moved quite substantially from his position just two years earlier in Muschinski v. Dodds (1985), 160 C.L.R. 583 (Aus. H.C.). In that case at 617, Deane J. said that there was no general principle of unjust enrichment in Australian law which could be used "as a basis of decision as distinct from an informative generic label for purposes of classification."

Supra note 9.

Baumgartner v. Baumgartner (1987), 164 C.L.R. 137 (Aus. H.C.), per Toohey J.

Ibid.; Muschinski v. Dodds, supra note 61; see generally M. Neave, "Three Approaches to Family Property Disputes - Intention/Belief, Unjust Enrichment and Unconscionability" in Youdan, ed., supra note 7 at 247.

The same is true in New Zealand. In Gillies v. Keogh, [1989] 2 N.Z.L.R. 327 (C.A.), for example, the New Zealand Court of Appeal, in addition to considering authorities from England, Australia and its own jurisdiction, cited a number of the decisions of the Canadian Supreme Court on the constructive trust to assist it in reaching the conclusion that, on the facts, no constructive trust should be imposed on property held by the "wife" in a de facto marriage. Although the Court did not necessarily endorse the Canadian approach based upon the principle of unjust enrichment, it expressed some sympathy with it.

(1988), 165 C.L.R. 107 (Aus. H.C.).

See also Deane J., ibid. at 145-146; see generally K. Mason Q.C., "Restitution in Australian Law" in Finn, ed., supra note 6 at 20, 32-36. 
In my view it should now be recognized that a promisor who has accepted agreed consideration for a promise to benefit a third party is unjustly enriched at the expense of the third party to the extent that the promise is unfulfilled and the non-fulfilment does not attract proportional legal consequences.

The possibility of unjust enrichment is obviated by recognition that a promisor who has accepted agreed consideration for a promise to benefit a third party owes an obligation to the third party to fulfil that promise and that the third party has a corresponding right to bring action to secure the benefit of the promise. ${ }^{68}$

There are some intractable problems with the proposed use of the law of restitution to cure defects in the contractual concept of privity. ${ }^{69}$ It would seem better for the courts to confront directly the rigid doctrine of privity of contract. In reality, the plaintiff is seeking to secure the benefit of a promise rather than to strip the defendant of some unjust enrichment made at the plaintiff's expense. The defendant's enrichment would appear to be the consideration received from the promisee and to have been made at the expense of the promisee rather than the plaintiff. Gaudron J.'s judgment is an illustration of the danger of viewing restitution, and the principle of unjust enrichment, as some universal solvent.

\section{APPLICATION OF THE PRINCIPLE OF UNJUST ENRICHMENT}

The early recognition by the Supreme Court of the principle of unjust enrichment has led to a number of innovative developments in the law of restitution where, again, the Supreme Court has played a leading role in the Commonwealth. In particular, attention will be focused upon the recognition of a defence of change of position, the recovery of benefits conferred under mistake, contribution among concurrent wrongdoers and the development of the remedial constructive trust.

\section{A. DEFENCE OF CHANGE OF POSITION}

The recognition by the Supreme Court of a generalized right to restitution based on the principle of unjust enrichment was instrumental in the later recognition by that Court of a general defence to a restitutionary claim of change of position. In Rural Municipality of Storthoaks v. Mobil Oil Canada Ltd., ${ }^{70}$ a case dealing with the recovery of money paid under mistake of fact, the Court adopted $^{71}$ the following provision from the Restatement of Restitution: 
The right of a person to restitution from another because of a benefit received is terminated or diminished if, after the receipt of the benefit, circumstances have so changed that it would be inequitable to require the other to make full restitution. ${ }^{72}$

The defence was rejected on the facts because the recipient, a municipality, was unable to establish that it had materially changed its circumstances as a result of the receipt of the money. No special projects had been undertaken and no special financial commitments had been made. The municipality had used the money to pay general everyday expenses. The important point, however, was that the defence was recognized and was seen as being separate from the more traditional, and narrowly circumscribed, defence of estoppel.

The major area of operation for such a defence will be in the context of payments made under mistake where its potential has been recognized on a number of occasions. ${ }^{73}$ The defence, however, has rarely succeeded ${ }^{74}$ and this may be in part because the courts are taking too rigid a view of its availability. ${ }^{75}$ In particular, much reliance has been placed upon the words of Dickson J. in Hydro Electric Commission of Nepean v. Ontario $\mathrm{Hydro}^{76}$ that the mere spending of the money "beyond recall" ${ }^{77}$ is not sufficient to establish the defence. There is certainly scope for the defence to be developed more fully in Canada and for its extension to other areas of restitution. In the latter context, it is interesting to observe that the British Columbia Court of Appeal, ${ }^{78}$ relying upon Storthoaks, ${ }^{79}$ has recognized the principle that a recipient of money paid under compulsion can defend an action for its recovery by showing that it would be unjust to compel it to reimburse the plaintiff.

Only recently has such a defence even been mooted as a possibility in Australia ${ }^{80}$ and finally been accepted in England. The latter decision was that of the House of Lords in Lipkin Gorman v. Karpnale Ltd. ${ }^{81}$ where the Court gave effect to such a defence in the context of the recovery of stolen money used by the thief to gamble at the defendant's club. The plaintiff's claim was restricted to such money as the thief had lost at the defendant's casino, taking into account the course of betting as a whole. It was decided that it would be inequitable to require the defendant to repay in full the plaintiff's money

Supra note $10, \S 142(1)$.

For example, see Hydro Electric Commission of Nepean v. Ontario Hydro (1982), 132 D.L.R. (3d) 193 at 212-215 (S.C.C.), per Dickson J. [hereinafter Ontario Hydro]; Air Canada v. R. in Right of British Columbia, [1989] 4 W.W.R. 97 at 130 (S.C.C.), per La Forest J. [hereinafter Air Canada]. For one recent decision where the defence did succeed, see Morgan Guaranty Trust of New York v. Outerbridge (1990), 66 D.L.R. (4th) 517 (Ont. H.C.).

See G. Jones, "A Topography of the Law of Restitution" in Finn, supra note 6 at 12-18. Supra note 73.

Ibid. at 212, relying upon Denning L.J. in Larner v. London County Council, [1949] 2 K.B. 683 at 688 (C.A.) who was speaking in the context of the defence of estoppel.

See A.J. Seversen Inc. v. Qualicum Beach, [1982] 4 W.W.R. 374 (B.C.C.A.).

Supra note 70.

Australia and New Zealand Banking Group Ltd. v. Westpac Banking Corp. (1988), 164 C.L.R. 662 at 673 (Aus. H.C.).

Supra note 17. Just two years earlier Dillon L.J. in the English Court of Appeal in Rover International Ltd. v. Cannon Film Sales Lid. (No. 3), [1989] 3 All E.R. 423 at $442-43$ had denied the existence of any general defence of change of position in English law. 
used in gambling without taking into account winnings paid by the defendant to the gambler. The scope of the defence of change of position was left deliberately vague so as not to inhibit its future development on a case by case basis. Lord Goff, in giving the leading judgment, said simply that "the defence is available to a person whose position has so changed that it would be inequitable in all the circumstances to require him to make restitution, or alternatively to make restitution in full." ${ }^{182}$

The only restrictions on the availability of the defence to be specifically endorsed were that it was not open to protect a party who had changed his or her position in bad faith, such as where the defendant had paid away the money with knowledge of the facts entitling the plaintiff to restitution, nor to a wrongdoer. Moreover, the mere spending of the money even in good faith would not necessarily give rise to the defence "because the expenditure might in any event have been incurred by [the recipient] in the ordinary course of things." 83 In recognizing the defence for the first time, the Court drew support from, amongst other things, the decision of the Supreme Court of Canada in Storthoaks. ${ }^{84}$

The House of Lords also pointed out the advantages offered by a defence of change of position over the more traditional defence of estoppel. In particular, there was no need to establish that the defendant had changed his or her position in reliance upon some representation by the claimant. Also, change of position, unlike estoppel, ${ }^{85}$ could operate as a partial defence to a claim in restitution.

\section{B. RECOVERY OF BENEFITS CONFERRED UNDER MISTAKE}

For a long time, the law of restitution has been bedeviled by the need to draw a distinction between mistakes of fact and mistakes of law. Whereas money paid under mistake of fact was generally recoverable, money paid under mistake of law was not. The leading case was Bilbie v. Lumley ${ }^{86}$ where Lord Ellenborough C.J. denied relief on the basis of the principle that ignorance of the law was no excuse. He said: "[e]very man must be taken to be cognizant of the law; otherwise there is no saying to what extent the excuse of ignorance might not be carried. It would be urged in almost every case. ${ }^{187}$

Clearly the invocation of the ignorantia juris maxim was not a compelling justification for the denial of relief, as was pointed out by Dickson J. in Hydro Electric Commission of Nepean v. Ontario Hydro:

Ibid.

Supra note 70.

See Avon County Council v. Howlett, [1983] 1 All E.R. 1073 (C.A.).

(1802), 102 E.R. 448 (K.B.).

Ibid. at $449-50$. 
There is a rule of law that in certain cases ignorance of law excuses no one; but there is no presumption that every one knows the law. The maxim ignorantia juris non excusat has no relevance to the case of a man seeking to recover back money paid by him in misapprehension of his legal rights....88

The unsatisfactory nature of the rule was illustrated by the substantial number of exceptions that came to be recognized by the courts. ${ }^{89}$ The exceptions threatened to swamp the rule itself. A change was first wrought in Canada by the judgment of Dickson $\mathrm{J}$. in the Ontario Hydro case..$^{90}$ In addition to questioning the basis for the rule, he showed that there was in fact little authority in its support, that many of the decisions in which recovery had been denied, including Bilbie v. Lumley ${ }^{91}$ itself, could be justified on the ground that the money had been paid in settlement of an honest claim and that the rule had become a convenient hook upon which courts could deny relief where the same result could be reached using a more sophisticated analysis. Ultimately, he concluded that the rule could not stand with the recognition in Canada of the principle of unjust enrichment. Payments made under a mistake, whether of fact or of law, would prima facie render the payee's retention of the money unjust. He said: "[o]nce a doctrine of restitution or unjust enrichment is recognized, the distinction as to mistake of law and mistake of fact becomes simply meaningless. ${ }^{192}$

Although Dickson J. was expressing his view in dissent, with Laskin C.J. concurring, it should be noted that the majority, in a judgment given by Estey J., expressly refrained from either endorsing or rejecting Dickson J.'s opinion on the ground that counsel for the appellant (plaintiff) had not raised the general principle of unjust enrichment and had not sought for the abolition of the distinction between mistakes of fact and mistakes of law. ${ }^{93}$

In the recent decision of Air Canada v. R. in Right of British Columbia ${ }^{94}$ a majority of the Supreme Court has now come out in favour of abolishing any distinction between mistakes of fact and mistakes of law in the context of the law of restitution. ${ }^{95}$ La Forest J. said:

In my view the distinction between mistake of fact and mistake of law should play no part in the law of restitution. Both species of mistake, if one can be distinguished from the other, should, in an appropriate case, be considered as factors which can make an enrichment at the plaintiff's expense "unjust" or "unjustified." This does not imply, however, that recovery will follow in every case where a mistake has been shown to exist. If the defendant can show that the payment was made in settlement of an honest claim, or that he has changed his position as a result of the enrichment, then restitution will be denied. ${ }^{96}$

Supra note 73 at 22.

See generally Goff \& Jones, supra note 2 at 124-35; Maddaugh \& McCamus, supra note 3 at 262-76.

Supra note 73. See generally "Dickson C.J. and Restitution", supra note 8 at 353-362.

Supra note 86.

Supra note 73 at 209.

Ibid. at 243.

Air Canada, note 73. See generally S. Arrowsmith, "Restitution and Mistake of Law in Canada" (1990) 106 L.Q. Rev. 28; "Restitution and the Supreme Court", supra note 8 at 510-20.

La Forest J., with Lamer and L'Heureux-Dubé JJ. concurring, and Wilson J. The other two judges, Beetz and McIntyre JJ., did not address this question.

Supra note 73 at $129-30$. 
Despite this welcome dismantling of the mistake of law doctrine, La Forest J.'s judgment is not without controversy. First, he held that the plaintiffs could not recover payments of what they argued to be an unconstitutional tax because they had passed on that burden to their customers and, therefore, it could not be said that the recipient, the province, had made a gain at the plaintiffs' expense. ${ }^{97}$ Any such defence, as contemplated by La Forest J., should have been the subject of closer scrutiny by the Court. It seems strange that the fact that the payer has adjusted its affairs so that it can afford to make the payments in question should give rise to an argument that it has not lost anything. As between the payer and the recipient, there seems little reason why the latter should be allowed to retain the money.

Secondly, La Forest J. determined that, as a matter of policy, taxes levied under unconstitutional legislation, as opposed to taxes extracted through a misapplication of valid legislation, should not be recoverable by the taxpayer because of the need to protect the treasury from the fiscal chaos that would otherwise result and to avoid the need to reimpose a similar tax on the same or on a new generation of taxpayers. ${ }^{98}$ It is hard to disagree with Wilson J.'s vigorous dissent on this issue:

\begin{abstract}
Why should the individual taxpayer, as opposed to taxpayers as a whole, bear the burden of government's mistakes? I would respectfully suggest that it is grossly unfair that $\mathrm{X}$, who may not be (as in this case) a large corporate enterprise, should absorb the cost of government's unconstitutional act. . . The loss should not fall on the totally innocent taxpayer whose only fault is that it paid what the legislature improperly said was due. I find it quite ironic to describe such a person as "asserting a right to disrupt the government by demanding a refund" or "creating fiscal chaos" or "requiring a new generation to pay for the expenditures of the old." ${ }^{199}$
\end{abstract}

In fact, her statement of general principle should have been conclusive of the issue: "Where the payments were made pursuant to an unconstitutional statute, there is no legitimate basis on which they can be retained. ${ }^{100}$

In the United Kingdom, it appears that, for the moment, the traditional position of denying the recovery of money paid under mistake of law still stands. The issue arose tangentially in Woolwich, ${ }^{101}$ where the primary question was whether there was a general right to restitution of money paid to a governmental authority in response to an ultra vires or unconstitutional demand. Opinion ranged from Lord Keith, in the minority on the primary question, who thought that the rule favouring non-recoverability was "too deeply embedded in English jurisprudence to be uprooted judicially," 102 to Lord Jauncey, also in the minority, who doubted "whether in all cases the distinction between mistake

Ibid. at 131.

Ibid. at 131-35. The true scope of La Forest J.'s judgment was "left to another day" by McLachlin J. in Peel, supra note 40 at 166.

Ibid. at 106. See generally P. Birks, "Restitution from the Executive: A Tercentenary Footnote to the Bill of Rights" in Finn, ed., supra note 6 at 164 [hereinafter "Restitution from the Executive"]. Ibid. at 107.

Supra note 18. See the comment by G. Jones on the decision of the Court of Appeal, "Restitution of Unconstitutional Tax" (1992) 51 Camb. L.J. 29.

Supra note 18 at 374. 
of fact and of law [could] be justified any longer." ${ }^{\text {103 }}$ Of the judges in the majority, Lord Slynn suggested that the rule was "open to review"104 by the House of Lords; Lord Browne-Wilkinson did not address the question at all; and Lord Goff said that it was not necessary to determine whether the traditional rule should be abolished. ${ }^{105}$ Lord Goff, however, was clearly not in sympathy with the mistake of law doctrine. He referred to both Ontario Hydro ${ }^{106}$ and Air Canada ${ }^{107}$ and said that, in the former decision, "Dickson J. [had] subjected the rule against recovery of money paid under a mistake of law to a devastating analysis." 108

In Woolwich, a majority decided the primary question in favour of the claimant and determined that there was a general right to restitution of money paid to the government pursuant to an ultra vires demand. The leading judgment was that of Lord Goff. He made it clear that, in this context, recovery would not be barred because the claimant had paid the money under a mistake of law. To this extent, at least, he was prepared to do away with the mistake of law doctrine. Lord Goff also paid close attention to the judgment of the Supreme Court in Air Canada ${ }^{109}$ In that regard, he adopted the reasoning of Wilson $\mathrm{J}$. and rejected the limitation on recovery proposed by La Forest J. with respect to taxes levied under unconstitutional legislation. He did, however, leave for another day the question of whether the fact that the plaintiff has passed on the burden of the levy to others should provide a defence to the claim. ${ }^{110}$

\section{CONTRIBUTION AMONG CONCURRENT WRONGDOERS}

It is a well-recognized principle of equity that, where one party owes with others a common obligation to a third party, then the first party can claim contribution from those others should he or she be compelled to discharge the common obligation. This principle first found expression in the context of co-sureties. ${ }^{111}$ It is not, however, restricted to that category but applies to all co-obligors, such as co-insurers and joint contractors. ${ }^{112}$ The equitable principle, however, does not cover damage caused to the plaintiff by the breach of two or more independent contracts. Indeed, there is doubt as to the extent to which contribution is available in respect of damage flowing from a breach by two or more contracting parties of the same contract. ${ }^{113}$ Moreover, the equitable doctrine did not extend to tortfeasors. At common law, there could be no contribution among

\footnotetext{
$103 \quad$ Ibid. at 410.

104 Ibid. at 417.

105 Ibid. at 395.

$106 \quad$ Supra note 73.

107 Supra note 73.

108 Supra note 18 at 393.

109 Supra note 73.

110 In his judgment, Lord Goff, supra note 18 at 385 , expressed his debt to "the powerful essay" by $P$. Birks, "Restitution from the Executive", supra note 99 at 114, for Birks' elaboration of the right to restitution in these circumstances.

111 Deering v. Earl of Winchelsea (1787), 126 E.R. 1276 (Ex.).

$112 \quad$ See generally Goff \& Jones, supra note 2 at 272-89.

113 See generally The Law Commission, Working Paper No. 59, Contribution (1975) at 11-14.
} 
tortfeasors who, either combined as joint tortfeasors ${ }^{114}$ or through independent breaches of duty, ${ }^{115}$ caused the same damage to the plaintiff. The result was that one tortfeasor could be compelled to satisfy the whole of the plaintiff's claim without any means of redress from the other wrongdoers. That latter position has now been changed by statute. ${ }^{116}$

It is readily apparent, however, that certain categories of defendant do not fall within the protection of either the equitable or the statutory right to contribution. Thus, as seen, where a plaintiff has suffered the same damage from separate breaches of contract, no contribution would seem to be available among the contract breakers and one of them could be compelled to bear the brunt of the entire loss suffered by the plaintiff. The same position would be reached where the plaintiff's damage was caused by one defendant's breach of contract and another's tortious conduct. ${ }^{117}$ In an article, published in 1976, ${ }^{118}$ Professor Weinrib argued that, in such situations, a right to contribution should be recognized at common law based upon the principle of unjust enrichment. He wrote:

Given that $P$ can recover in full from D1, it would be unfair as between D1 and D2 to force D1 to pay all and allow D2 to escape with paying none of the damages for which each is wholly liable. Contribution is the mechanism rooted in both equity and the common law which reflects this basic consideration of relative fairness. Inasmuch as D1 in discharging his own liability to $P$ has relieved D2 of any need on his part to satisfy his own obligation to P, D1 has under the compulsion of law been forced to confer a benefit on D2 to which D2 is not entitled and which the device of contribution would force him to disgorge. ${ }^{119}$

There is now some judicial support for this opinion in the form of dicta uttered by Laskin C.J. in Giffels Associates Ltd. v. Eastern Construction Ltd. ${ }^{120} \mathrm{He}$ said:

I am prepared to assume, for the purposes of this case, that where there are two contractors, each of which has a separate contract with a plaintiff who suffers the same damage from concurrent breaches of

Merryweather v. Nixan (1799), 101 E.R. 1337 (K.B.).

Horwell v. London General Omnibus Co. (1877), 2 Ex. D. 365 at 379 (C.A.), per Kelly C.B.

In Alberta, see Tort-Feasors Act, R.S.A. 1980, c. T-6. There are also some contribution provisions in the Contributory Negligence Act, R.S.A. 1980, c. C-23, but, in the event of a conflict between the two statutes, the Tort-Feasors Act takes precedence as being more specifically directed to the question of contribution among tortfeasors: see County of Parkland No. 31 v. Stetar, [1975] 1 W.W.R. 441 at 450-51 (S.C.C.), per Dickson J.

In general, the courts have not been receptive to the view that the statutory provisions governing contribution apply to concurrent contract breakers or to a mixture of tortfeasors and contract breakers who contribute to the common damage: see e.g. Dominion Chain Co. v. Eastern Construction Co. Ltd. (1976), 68 D.L.R. (3d) 385 (Ont. C.A.); aff'd sub nom. Giffels Associates Ltd. v. Eastern Construction Co. Ltd. (1978), 84 D.L.R. (3d) 344 (S.C.C.). Contribution may be allowed under the statutes, however, where contract breakers are also found concurrently liable in tort: Dominion Chain Co. v. Eastern Construction Co. Lid., ibid.

E.J. Weinrib, "Contribution in a Contractual Setting" (1976) 54 Can. Bar Rev. 338.

Ibid. at 340.

Supra note 117. 
those contracts, it would be inequitable that one of the contractors bear the entire brunt of the plaintiff's loss, even where the plaintiff chooses to sue only that one and not both.... ${ }^{121}$

Given the lack of statutory reform in Canada, ${ }^{122}$ the glimmer of hope offered by Laskin C.J. for a judicial change of heart may prove to be very important.

\section{THE REMEDIAL CONSTRUCTIVE TRUST}

Probably the greatest innovation worked by the Supreme Court in the law of restitution has been the development of the constructive trust as a general restitutionary remedy ${ }^{123}$ Much of this development in the context of family law has already been traced through the earlier discussion of Murdoch, ${ }^{124}$ Rathwell ${ }^{125}$ and Petikus. ${ }^{126}$ It is still in that area that the constructive trust plays its most significant role, its appearance in other contexts being fairly limited. Indeed, in family law cases, the granting of proprietary relief to a disappointed spouse or cohabitee has become something of the norm once the conditions for an unjust enrichment have been satisfied. It is, therefore, encouraging to see that, in Sorochan v. Sorochan, ${ }^{127}$ the Supreme Court divorced the finding of an unjust enrichment from the question of the appropriateness of proprietary relief. In determining that the imposition of a constructive trust was indeed fitting, Dickson C.J. isolated the fact that there had to be a sufficiently substantial connection between the contribution of the plaintiff and the acquisition, maintenance or preservation of the asset in question. In addition, he stressed the requirements that the claimant must reasonably have expected to receive an interest in the property in issue and that the defendant must have known, or at least ought reasonably to have been aware, of that expectation. He also saw the longevity of the relationship as being a significant factor in the determination of whether proprietary relief should be awarded. Dickson C.J. specifically drew a distinction between the family and the commercial spheres. In the latter situation, he determined that the courts should scrutinize the relationship between the parties more closely in deciding whether to impose a constructive trust. ${ }^{128}$ One reason why a plaintiff will seek a

Ibid. at 350.

Alberta's Institute of Law Research and Reform, for example, in 1979 recommended legislative reform in this context (see Report No. 31, Contributory Negligence and Concurrent Wrongdoers) but, as yet, no action has been taken on that report. See also Ontario Law Reform Commission, Report on Contribution Among Wrongdoers and Contributory Negligence (Ministry of the Attorney General, 1988). Reforms have, however, been implemented in the United Kingdom, see Civil Liability (Contribution) Act, 1978, 1978, c. 47.

See generally J.L. Dewar, "The Development of the Remedial Constructive Trust" (1982) 60 Can. Bar Rev. 265; M.M. Litman, "The Emergence of Unjust Enrichment as a Cause of Action and the Remedy of Constructive Trust" (1988) 26 Alta. L. Rev. 407; D.M. Paciocco, "The Remedial Constructive Trust: A Principled Basis for Priorities Over Creditors" (1989) 68 Can. Bar Rev. 315; D.W.M. Waters, Q.C., "The Constructive Trust in Evolution: Substantive And Remedial" (1990-91) 10 Estates \& Trusts J. 334.

Supra note 46.

Supra note 48.

Supra note 52.

(1986), 29 D.L.R. (4th) 1 (S.C.C.).

Ibid. at 9, relying upon the words of Cory J.A. from Murray v. Roty (1983), 147 D.L.R. (3d) 438 at 444 (Ont. C.A.). 
constructive trust is to ensure priority over the general creditors of the defendant. It is significant that, in none of the leading decisions of the Supreme Court in the family law context, was this particular problem raised. It was, therefore, comparatively painless for the Supreme Court to grant proprietary relief.

Dickson C.J.'s approach was heavily endorsed by Cory J., speaking for himself and L'Heureux-Dubé and Gonthier JJ. in Peter v. Beblow. ${ }^{129}$ While he stressed the importance of divorcing the question of whether there had been an unjust enrichment from the question of the appropriate relief, Cory J. determined that, in family cases, there was not the same need, as in the commercial context, to establish a clear link between the plaintiff's contributions and the property which was said to be the subject of the trust. He wrote:

[T]here is a need to limit the use of the constructive trust remedy in a commercial context. Yet I do not think the same proposition should be rigorously applied in a family relationship. In a marital or quasimarital relationship, the expectations the parties will have regarding their contributions and interest in the assets acquired are, I expect, very different from the expectation of the parties engaged in a commercial transaction. As I have said, it is unlikely that couples will ever turn their minds to the issue of their expectations about their legal entitlements at the outset of their marriage or common law relationship. If they were specifically asked about their expectations, I would think that most couples would probably state that they did not expect to be compensated for their contribution. Rather, they would say, if the relationship were ever to be dissolved, then they would expect that both parties would share in the assets or wealth that they had helped to create. Thus, rather than expecting to receive a fee for their services based on their market value, they would expect to receive, on a dissolution of their relationship, a fair share of the property or wealth which their contributions had helped the parties to acquire, improve, or to maintain. The remedy provided by the constructive trust seems to best accord with the reasonable expectations of the parties in a marriage or quasi-marital relationship. ${ }^{130}$

In that vein, Cory J. specifically pointed out that, in the family context, it might be inappropriate to grant the constructive trust remedy to the prejudice of innocent third parties.

In contrast, McLachlin J., with the support of La Forest, Sopinka and Iacobucci JJ., rejected both the need for and the wisdom of drawing a distinction between family and commercial cases. She believed that "the creation of special rules for special situations might have an adverse effect on the development of this emerging arena of equity."131 She did, however, admit that "the courts should exercise flexibility and common sense when applying equitable principles to family law issues with sensitivity to the special circumstances that can arise in such cases." ${ }^{132}$

Whatever the outcome of this difference of opinion, it is clear that the courts are reluctant to overuse the remedy of constructive trust in the commercial arena and the Supreme Court has emphasized especially the need to consider the question of the 
appropriateness of proprietary relief in commercial cases once the question of unjust enrichment has been determined. ${ }^{133}$ The leading decision is LAC Minerals Ltd. v. International Corona Resources Ltd. ${ }^{134}$ The case centred upon the misuse of confidential information obtained by the defendant, LAC, in the course of negotiations with the plaintiff, Corona, towards a joint venture arrangement for the acquisition and development of land as a gold mine. The defendant had used that information to purchase on its own behalf the mining rights in a property that the plaintiff was also attempting to acquire. Having determined that the plaintiff had made out a case of unjust enrichment on the ground of breach of confidence, La Forest J., giving the leading judgment on this question, turned his attention to the appropriate remedy. He agreed that the imposition of a constructive trust was but one restitutionary remedy and that in the vast majority of cases it would not be the most suitable form of relief. Normally, the plaintiff's claim could be satisfied by a purely personal monetary award and, often, the granting of proprietary relief would place the plaintiff in an overly favourable position in relation to the defendant's other creditors. La Forest J. determined, however, that on these facts proprietary relief was warranted. He said that "a proprietary claim should be granted when it [was] just to grant the plaintiff the additional benefits that flow[ed] from the recognition of a right of property,"1135 such as where it was appropriate that the plaintiff receive priority over the defendant's assets in a bankruptcy. That particular consideration was not crucial in $L A C$ itself. Instead, La Forest J. relied on the fact that the property in question was unique, that Corona would have acquired it but for LAC's intervention through a misuse of confidential information, that it was virtually impossible to value the property and that any increases in its value should accrue to Corona rather than to the wrongdoer, LAC. He also said that the imposition of a constructive trust in the case would have the meritorious effect of encouraging bargaining in good faith.

In the course of his judgment, La Forest J. clearly indicated the remedial nature of the restitutionary constructive trust. Thus, its imposition was not dependent in any way upon the existence of a fiduciary relationship between the parties. ${ }^{136}$ Indeed, La Forest $\mathrm{J}$. deplored the tendency of courts to invent a fiduciary relationship for the sole purpose of awarding proprietary relief. ${ }^{137}$ Equally, he emphasized the fact that the imposition of a constructive trust was not restricted to the recognition of some existing right of property but could itself create a right of property.

Of course, here too the unjust enrichment of the defendant must be established before there is any need to discuss the appropriate remedy to be awarded: Hunter Engineering Co. Inc. v. Syncrude Canada Ltd., [1989] 3 W.W.R. 385 (S.C.C.). See generally "Restitution and the Supreme Court", supra note 8 at 533-42 and "Dickson C.J. and Restitution", supra note 8 at 362-66. (1989), 61 D.L.R. (4th) 14 (S.C.C.) [hereinafter LAC Minerals]. See generally "Restitution and the Supreme Court", ibid. (Supreme Court L.R.) at 520-33. LAC Minerals, ibid. at 50. Minerals. This view, however, was a minority one supported by Wilson J. but rejected by McIntyre, Lamer and Sopinka JJ. 
La Forest J.'s judgment was in marked contrast to the minority view of Sopinka J., with which McIntyre J. concurred. Sopinka J. expressed a reluctance to impose a constructive trust where there was no fiduciary or other special relationship between the parties. He was also in favour of restricting its use to the recognition of existing rights of property and he determined that confidential information was not in itself property. In light of these considerations - and of the fact that it was impossible to assess the extent to which the confidential information, as opposed to public information, had influenced LAC to purchase the property in question - Sopinka J. awarded Corona damages for LAC's misuse of confidential information. He held that, but for LAC's breach, a joint venture agreement would have been concluded whereby each party would probably have acquired a half interest in the property. Corona's damages, therefore, were assessed at fifty percent of the value of the mine. It is submitted that La Forest J.'s reasoning on the appropriate remedy is more persuasive and points the way of the future. As he indicated, the effect of Sopinka J.'s judgment was not to encourage LAC to bargain in good faith because, by failing to do so, LAC was placed in the same position as if an agreement had been reached between the parties. It, therefore, had everything to gain by acquiring the property on its own account and nothing to lose. La Forest J. said:

If by breaching an obligation of confidence one party is able to acquire an asset entirely for itself, at a risk of only having to compensate the other for what the other would have received if a formal relationship between them were concluded, the former would be given a strong incentive to breach the obligation and acquire the asset. ${ }^{138}$

The Canadian courts have been accused of scattering constructive trusts "freely like confetti at a wedding." ${ }^{139}$ In fact, outside of the area of family law, they have been circumspect in their exercise of this new jurisdiction. Of course mistakes have been made. ${ }^{140}$ The decision of La Forest $\mathrm{J}$. in LAC Minerals, however, has opened the way for the courts, having made the determination that an unjust enrichment has occurred, to consider closely the appropriateness of granting the claimant the benefits of proprietary relief. In the future, much attention will have to be paid to the general question of when the imposition of a constructive trust is appropriate. Some of this work has already been started by writers in the field. ${ }^{141}$

In the future, the courts must still to come to grips with the true nature of the remedial constructive trust. A substantial divergence of judicial opinion was disclosed in the recent decision of Rawluk v. Rawluk ${ }^{142}$ There, the primary question raised was whether the doctrine of the constructive trust had survived the enactment of Ontario's Family Law Act,

Supra note 134 at 47.

G. Jones, "The Dynamics of the Common Law" in F.E. McArdle, ed., The Cambridge Lectures 1987 (Montreal: Les Éditions Yvon Blais, 1989) at 381, 385.

A good example may be Taypotat v. Surgeson, [1985] 3 W.W.R. 18 (Sask. C.A.). See the criticism by Paciocco, supra note 123 at 343.

For example, see T.G. Youdan "The Fiduciary Principle: The Applicability of Proprietary Remedies" in Youdan, supra note 7 at 93; Paciocco, ibid.; Maddaugh \& McCamus, supra note 3 at 93-100; J.D. McCamus, "Remedies for Breach of Fiduciary Duty" (1990) L.S.U.C. - Spec. Lect. 57.

(1990), 65 D.L.R. (4th) 161 (S.C.C.) [hereinafter Rawluk]. See the excellent discussion by Waters, supra note 123. 
$1986 .{ }^{143}$ That statute provided for the equalization of net family property according to its value at the prescribed valuation date, which in that case was the date of separation. Since the time of separation, however, certain properties held in the husband's name had risen substantially in value and the wife was seeking to share in that increase in value through the imposition of a constructive trust. In the course of his judgment for the majority of the Supreme Court in favour of the wife's position, Cory J. determined that, when a court decides to impose a constructive trust, the proprietary interest is deemed to have arisen when the unjust enrichment first occurred. ${ }^{144}$ A strong minority, however, stressed the remedial nature of the constructive trust and determined that, only when the trust is declared, does the beneficiary obtain a proprietary interest although that interest may, in the court's discretion, be taken as extending back to the time when the enrichment took place. ${ }^{145}$ It castigated the majority for regarding the constructive trust as, in effect, a substantive institution of the law of property. This difference in emphasis may not seem important, but it strikes at the heart of the concept of the remedial constructive trust. ${ }^{146}$ One practical ramification will be that those courts following the minority approach will pay closer attention to the adequacy, or otherwise, of the non-proprietary remedies available to the claimant.

The minority was also able to dispose of the troublesome decision of McDonald v. $M c D o n a l d^{147}$ that dealt with the converse problem to that raised in Rawluk. ${ }^{148}$ There, a husband was allowed to erect a constructive trust against his wife so as to compel her to share in a decline in value in property, held by him, occurring after the statutory valuation date. In discussing McDonald, McLachlin J. said:

So we arrive at the anomaly of the equitable remedy of constructive trust's being applied against the wishes of the party found to have been unfairly treated, at the behest of the party who has been unjustly enriched. What does this leave of the notion that he who seeks the aid of equity must come with clean hands? The fallacy at the root of such an approach is that of treating the remedy of constructive trust as though it were a property interest, which for the sake of consistency must be imposed regardless of the circumstances or of other remedies. ${ }^{149}$

The courts will also have to consider the relationship between the new remedial constructive trust designed to rectify unjust enrichment and the institutional or substantive constructive trust originally recognized by the courts in the context of breaches of duty by trustees and other fiduciaries. In Atlas Cabinets and Furniture Ltd. v. National Trust

S.O. 1986, c. 4 (now Family Law Act, R.S.O. 1990, c. F.3).

Supra note 142 at 176-77.

Ibid. at 183-88, per McLachlin J. See also Atlas Cabinets and Furniture Ltd. v. National Trust Co., supra note 56 at 173 , per Lambert J.A.:

A remedial constructive trust is a trust imposed by court order as a remedy for a wrong.

The entitlement to that remedy may be a matter of substantive law, but the trust itself is not created by the acts of the parties, or even by the obligation to make restitution, but by the order of the court. As with other court orders, the trust will come into being when the order is pronounced, unless, in an appropriate case, the order is made retroactive or its coming into force is deferred.

See Waters, supra note 123.

(1988), 11 R.F.L. (3d) 321 (Ont. H.C.) [hereinafter McDonald].

Supra note 142.

Ibid. at 191 [emphasis in the original]. 
Co. ${ }^{150}$ for example, Lambert J.A. determined that the substantive constructive trust still existed despite the evolution of the remedial constructive trust. ${ }^{151}$ Moreover, there were, to him, important distinctions between the two concepts. In particular, Lambert J.A. said that the court has no discretion to refuse to award a substantive constructive trust. Once the wrongful conduct has occurred, the substantive constructive trust is in existence. ${ }^{152}$

Another potential area of dispute came to the fore in Peter v. Beblow, ${ }^{153}$ that is the manner in which the extent of the trust should be determined, especially in family cases. The majority under McLachlin J. favoured what she termed the "value survived" approach, namely the amount by which the property had been improved by the claimant's services. On the other hand, Cory J. for the minority believed that, in the interests of flexibility, the courts should occasionally be able to use the "value received" approach, namely the amount that the defendant would have to pay for the claimant's services on a purely business basis to some independent third party.

\section{CONCLUSION}

Over the years, the Supreme Court of Canada has played a very significant role in the development of the law of restitution, with, amongst other things, its early recognition of the defence of change of position, its rejection of the mistake of law doctrine and its embracement of the remedial constructive trust. Largely due to the efforts of the Supreme Court, restitution can take its place as an independent and increasingly mature part of the private law of obligations. Moreover, the Court's pioneering work has at last come to be appreciated in the United Kingdom and other parts of the Commonwealth.

Despite the progress made, much still remains to be done in continuing to explicate the principle of unjust enrichment. Even within the narrow confines of the topics covered in this paper, a number of areas have been identified in which further work is required, such as the elaboration of the defence of change of position, the limitations, if any, to be imposed on restitutionary relief from governmental authorities and the proper place for proprietary restitutionary remedies. All that can be hoped for is that the next twenty-five years of judicial development will be as exciting and as fruitful as the last twenty-five years.

Is1 In Rawluk v. Rawluk, supra note 142 at 184-85, McLachlin J., for the minority, left open the relationship between the remedial and the institutional constructive trust. The majority expressed no view on this issue. See the discussion by Waters, supra note 123 at 375-82. See also Paciocco, supra note 123 at 318-21. 